\title{
QUANTIZATION OF REPRODUCTIVE STRUCTURES IN RELATION TO THE VASCULARIZATION OF SUNFLOWER CAPITULUM (Helianthus annuus L.) DURING ITS DEVELOPMENT
}

\author{
A.C. Martínez Tosto*, F.J . Cardinali \\ Laboratorio de Botánica, Universidad Nacional de Mar del Plata \\ Funes 3250 (7600) Mar del Plata, Argentina
}

Received: December 24, 1999

Accepted: September 04, 2001

SUMMARY

The objective of this work was to determine the number of reproductive structures in relation to the vascularization of sunflower capitulum in three sectors: outer, middle and center, and in four development stages: $E_{2}$ (early floral button), $E_{4}$ (late floral button), $F_{3.2}$ (beginning flowering) and $M_{0}$ (end flowering) according to the CETIOM code.

Seeds of Dekalb G100 sunflower hybrid were sown at $72.000 \mathrm{pl} / \mathrm{ha}$ density and the capitula gathered at the indicated stages.

At each stage, significant increases were noticed in the reproductive structures number from the outer sector to the center of capitulum. The number of vascular bundles per unit of surface showed a significant decrease from the outer sector to the center at $E_{2}$ and $E_{4}$ stages and a tendency to become stable at $F_{3.2}$ and $M_{0}$. The obtained values of surface covered by phloem per $\mathrm{cm}^{2}$ of capitulum, decreased remarkably from the outer sector to the center at $\mathrm{E}_{4}$ stage while at $F_{3.2}$ and $M_{0}$ minor but still important decreases were observed.

The statistical analysis made on reproductive structures number in relation to vascular bundles number and surface covered by phloem showed low and insignificant correlations, respectively.

Key words: capitulum, development stages, reproductive structures, phloem, sunflower, vascular bundles

\section{INTRODUCTION}

In the capitulum of sunflower (Helianthus annuus L.), the flowering, fertilization and the posterior fruit development occur in centripetal order which determines different grades of differentation and maturation of the reproductive structures from the outer part to the center at every stage.

* Corresponding author, e-mail: amtosto@mdp.edu.ar, cardinal@mdp.edu.ar 
The number of florets that is distinguished at the initial stages of sunflower capitulum development varies according to cultivation from 890 to 4540 (Villalobos et al., 1994). The number of full seeds changes between $60 \%$ and $80 \%$ of the number of different florets depending on the hybrid studied (Villalobos et al., 1994). In other agro-economic species such as wheat, important losses of reproductive structures were observed at different development stages of cultivation. In that species, the number of grains obtained was always lower than the number of florets at flowering and the loss of florets averaged $43 \%$ and occurred at two moments of the plant life cycle, one between the differentiation of the top of the spikelet and flowering and another one immediately afterwards (Bodega, 1994).

In sunflower the number of florets per unit of receptacle surface at early stages of capitulum development has not been extensively studied but there are many information for physiologic maturity that show great variability in the different zones, with a smaller number in the outer zone increasing toward the center. However, the number of full seeds decreases from the outer zone to the center being clearly lower in the central section (Goffner et al., 1988; Steer et al., 1988; Sinsawat et al., 1993). This fact is due, among another reasons, to capitulum vasculature being deficient in this central sector (Durrieu et al., 1985).

Other authors have indicated that the vasculature in the central zone of the capitulum would not be limiting for the filling of fruits placed there (Goffner et al., 1988; Steer et al., 1988).

Anatomical studies of the sunflower capitulum show the vascular bundles penetrate ascendently from the outer zone; approaching the section of fruit insertion, then branch inside the receptacle and go up vertically to them (Thevenon, 1996).

Specific studies of the phloem vasculature made in the hybrid Dekalb G 100 capitula at physiologic maturity and flowering (Thevenon, 1996) showed that the components of phloem tissue were found to be fully differentiated at both stages. Due to a lack of knowledge of phloem differentation in the previously mentioned periods, it is necessary to investigate the development stage of the mentioned tissue in the period previous to the grain filling stage considered as the critical phase for the abortion of seed: 20 days previous and after $50 \%$ anthesis (Chimenti and Hall, 1996) to know if the development of phloem could be a limit for fruit nutrition.

The objective of this work was to determine the number of generated and lost reproductive structures, the vasculature (phloem tissue cover and number of vascular bundles per unit of surface) and their relationship in the three sectors of the capitulum: outer zone, middle and center and at four development stages: $E_{2}, E_{4}$, $\mathrm{F}_{3.2}$ and $\mathrm{M}_{0}$ according to the CETIOM code (Merrien, 1986).

\section{MATERIALS AND METHODS}

Seeds of Dekalb G 100 sunflower hybrid were grown in an argiudol soil which is typical for the experiment field of the Integrated Unit, Agriculture Science Faculty, 
Mar del Plata National University on $30^{\text {th }}$ November 1993 at $72.000 \mathrm{pl}^{-1} \mathrm{a}^{-1}$ density. The cultivation during its cycle was mantained in good condition of water nutrition and free of weeds and pes.

Capitula of 32 randomly chosen plantswere harvested at the development stages $E_{2}$ (early floral button), $E_{4}$ (later floral button), $F_{3.2}$ (flowering beginning) and $M_{0}$ (flowering end), with diameters of $1.85( \pm 0.21) \mathrm{cm}, 5.25( \pm 0.35) \mathrm{cm}, 9.5( \pm 0.70)$ $\mathrm{cm}$ and $14.5( \pm 0.70) \mathrm{cm}$ for each stage, respectively. Inmediately after cutting the capitula, they were fixed with FAA solution (D`Ambrogio de Argueso, 1986).

In each analyzed capitulum, transects were cut between 0.5 and $1 \mathrm{~cm}$ width from the capitulum central point. Each transect was divided in three sectors, each equal to $1 / 3$ of the capitulum radius. This determined the three study zones: outer, middle and center.

To determine the number of reproductive structures, we used 3 capitula for each stage. At $E_{2}$ and $E_{4}$ each transect was processed utiliging the paraffin inclusion technique (D`Ambrogio de Argueso, 1986). Later, cross section cuts of $15 \mu \mathrm{m}$ were made of floret primordia level with a rotatory microtome. These were colored with Toluidine Blue (water solution $0.05 \%$ ) and assembled with Balsam of Canadian. The slides were observed with an optic microscope. The data about each capitulum sector were obtained placing the squares at random (methodology described in Matteucci and Colma (1982) for the vegetation study) at 2 and $2.5 \mathrm{~mm}$ sides drawn on acetate paper, for development stages $E_{2}$ and $E_{4}$, respectively. At $F_{3.2}$ and $M_{0}$ stages the collection of samples was made by punching out pieces $1 \mathrm{~cm}$ in diameter in each sector. The determination of floret number was made macroscopically by direct visual observation.

To determine the number of vascular bundles, 3 capitula were used for each stage. The samples were processed by the paraffin inclusion technique ( ${ }^{`}$ 'Ambrogio de Argueso, 1986). Subsequently cross and Iongitudinal section cuts were made of $10 \mu \mathrm{m}$ thickness and at the seed insertion level for the cross section cuts. The data for capitulum sectors were obtained using the acetate square methodology described for the determination of the florets number but of $2 \mathrm{~mm}$ of side for $E_{2}$ and $\mathrm{E}_{4}$ stages and $2.5 \mathrm{~mm}$ for $\mathrm{F}_{3.2}$ and $\mathrm{M}_{0}$.

The phloem cover measuring was made onto the same slides used for the determination of the vascular bundles number but in this case random collection of samples was made with a grid drawn on acetate paper of $0.09 \mathrm{~cm}^{2}$ of a total surface composed by 9 squares of $0.01 \mathrm{~cm}^{2}$. The determinations were made with an optic microscope and the data were expressed in phloem tissue surface values.

The results of the measured parameters were refered at $\mathrm{cm}^{2}$ of receptacle and analyzed statisticaly by means of variance analysis (ANOVA) with a $5 \%$ significance level. Averages with significant differences were compared by the Tuckey test.

The values of the relationship among the number of reproductive structures, the number of vascular bundles and phloem cover surface in at stages studied were analyzed statistically by the correlation coefficient calculus. 


\section{RESULTS AND DISCUSSION}

At each development stage studied, significant increases of the number of reproductive structures from the outer zone to the center of the capitulum (Table 1) were observed. These results correspond to the continuous expansion of the sunflower capitulum. In fact, this organ has particular growing dynamics with the center having low or null expansive activity and the peripheral generative area retaining a major rhythm of cellular expansion (Hernández, 1995). This determines a maximum available space for each reproductive structure in the outer zone and minimum in the central zone. On the other hand, an important decrease of the reproductive structures was observed from $E_{2}$ to $M_{0}$. Also, capitulum expansion plays an important role on this parameter along the ontogenics cycle, nevertheless, the totality of the loss could not be explained by the mentioned expansion which oneself thinks that the sunflower plant carries additional ajustes outs makes as an answer to source/sink relations generated during the growth. Because of that, while the capitulum expands its surface 61.6 times from $E_{2}$ to $M_{0}$, the number of reproductive structures per unit of surface (NER), considering the total capitulum, decreases on average 133 times within the same period. So the capitulum expansion explains only $46.3 \%$ of the losses. It is necessary to clarify that the mentioned expansion would explain the NER decrease that is confirmed in the generative zone, whereas the central zone with less or null expansion would fit such parameter taking into account the abortion of seeds.

Table 1: Capitula surface and structures number in different sectors and stages of sunflower capitulum

\begin{tabular}{lccccc}
\hline & & $\mathrm{E}_{2}$ & $\mathrm{E}_{4}$ & $\mathrm{~F}_{3.2}$ & $\mathrm{M}_{0}$ \\
\hline Capitulum total surface & & 2.688 & 21.647 & 70.882 & 165.13 \\
\hline NER* & $\mathrm{P}$ & $1047.5 \mathrm{a}$ & $116.8 \mathrm{a}$ & $15.57 \mathrm{a}$ & $7.98 \mathrm{a}$ \\
& $\mathrm{M}$ & $1130 \mathrm{~b}$ & $170.4 \mathrm{~b}$ & $22.82 \mathrm{~b}$ & $10.58 \mathrm{~b}$ \\
& $\mathrm{C}$ & $1972.5 \mathrm{C}$ & $240 \mathrm{C}$ & $31.15 \mathrm{C}$ & $12.66 \mathrm{c}$ \\
NERp & & 1383.3 & 175.7 & 23.18 & 10.40 \\
NERt & & 3718.31 & 3803.37 & 1643.04 & 1717.35 \\
\hline
\end{tabular}

NER: Reproductive structures number per $\mathrm{cm}^{2}$ of capitulum

NERp: Average reproductive structures number (outer zone (P), middle (M) and center (C)) per $\mathrm{cm}^{2}$ of capitulum

NERt: Reproductive structures number per capitulum total surfac.

* Inside each stage the average values of each column followed to the same letter do not differ significantly at $P<0.05$

Although mechanisms in the void of the number of seeds are hardly known, there are many information in the references. It appears that different effects of environmental, hormone, and genetic factors explain the rest of the lost. Because of this Goffner et al. (1988), Steer et al. (1988) and Sinsawat et al. (1993) suggested that the number of reproductive structures in the capitulum central zone of the capitulum is due to the lack of physical space for fruit development. However, Villalobos et al. (1994) noticed that decrease in the number of fertile reproductive structures was not due to the available space since different diameter capitula obtained 
from cultivars of distinct plant density had a similar number of florets. Anyway these voids made by the plant are essential since the sunflower, like the rest of the Compositae, produces a large number of reproductive structures that necessarily must be reduced a function of its providing capacity. The void can be clearly seen when the total NER of the capitulum at each phenologic stage obtained by integration of the NER of each sector is analyzed. Because of that, the total NER has least variations between $E_{2}$ and $E_{4}$ and $F_{3.2}$ and $M_{0}$; the large void happens between $E_{4}$ and $F_{3.2}$ that is to say in the previous period to anthesis the recaptacle loses $55.8 \%$ of the total reproductive structures present.

Table 2: Studied variables in different sectors and sunflower capitulum stages

\begin{tabular}{cccccc}
\hline & & $\mathrm{E}_{2}$ & $\mathrm{E}_{4}$ & $\mathrm{~F}_{3.2}$ & $\mathrm{M}_{0}$ \\
\hline $\mathrm{P}$ & $\mathrm{NHV} *$ & $745.31 \mathrm{a}$ & $121.71 \mathrm{a}$ & $40.8 \mathrm{a}$ & $20 \mathrm{a}$ \\
& $\mathrm{F} *$ & - & $0.187 \mathrm{a}$ & $0.195 \mathrm{a}$ & $0.192 \mathrm{a}$ \\
& $\mathrm{REH}$ & 1.4 & 0.97 & 0.40 & 0.40 \\
& $\mathrm{REF}$ & - & 624.6 & 79.8 & 41.56 \\
& $\mathrm{NHV} *$ & $550 \mathrm{~b}$ & $86.85 \mathrm{~b}$ & $50.4 \mathrm{~b}$ & $22 \mathrm{~b}$ \\
$\mathrm{M}$ & $\mathrm{F} *$ & - & $0.156 \mathrm{~b}$ & $0.18 \mathrm{~b}$ & $0.16 \mathrm{~b}$ \\
& $\mathrm{REH}$ & 2.05 & 1.91 & 0.45 & 0.47 \\
& $\mathrm{REF}$ & - & 1092.3 & 126.77 & 66.12 \\
$\mathrm{CH}$ & $\mathrm{NHV} *$ & $141.40 \mathrm{c}$ & $64.57 \mathrm{c}$ & $46.4 \mathrm{c}$ & $30 \mathrm{c}$ \\
\hline
\end{tabular}

NHV: Vascular bundles number per $\mathrm{cm}^{2}$ of capitulum

F: Surface cover to phloem $\left(\mathrm{cm}^{2}\right)$

REH: Relation reproductive structures number / vascular bundles number

Pearson correlation coeficient $r=0.60$

REF: Relation reproductive structures number / surface cover to phloem

Pearson correlation coeficient $r=0.073$

Vascular bundles were recognized in all sectors and at all stages; nevertheless, the collateral bundles typical of sunflower could only be clearly identified starting from $\mathrm{E}_{4}$. The number of vascular bundles per unit of surface (NHV) showed a permanent decrease along the ontogenic cycle in all sectors. Observations in each cycle stage showed for $E_{2}$ and $E_{4}$ high values in the outer sector which significantly decreased towards the capitulum center. The situation was reported in a different way in more advanced stages since in $\mathrm{F}_{3.2}$ the NHV in the outer zone was lower than those observed in the middle and center sectors in which there were no significant differences. The following stage $\left(\mathrm{M}_{0}\right)$ showed similar values in the outer and middle zones but lower than that in the center (Table 2 ). This shows a tendency to NHV stabilitazion that begins in the outer zone and is coincidental with the strong void in the number of reproductive structures. It happens starting from anthesis and gradually continues to physiologic maturity $\left(M_{2}\right)$. In this respect, Thevenon (1996), working on $\mathrm{M}_{2}$ with the same cultivars and similar experimental conditions, reported a similar NHV to the one given here for $\mathrm{M}_{0}$ except to the center zone where he found superior values.

A detailed study of the vascular bundles showed that the phloem tissue was little distinguished in $E_{2}$ which impeded the determination of the limits of this tissue 
and therefore its surface. For this reason the results were not included in Table 2. At $E_{4}$ there occurred an important differentiation process which allowed the identification of phloem tissue surface per capitulum surface $(F)$; nevertheless, minimum values of $F$ in the center zone were identified since the differentiation process progresses from the outer zone to the capitulum center which explains the decrease of this parameter. This extensive process allowed to identify just in $F_{3.2}$ ending sieve plates and lateral sieve areas of the sieve tube elements. The presence of these structures suggests phloem tissue distinguished totally since element autholisis to definitively become in a specialized element in the conducting (Esau, 1993). A tendency for stabilitazion from $F_{3.2}$ to $M_{0}$ was observed at this starting point. As a matter of fact, Thevenon (1996) confirms this tendency since the values of $F$ in his work do not present significant differences in different sectors of the capitulum at a stage more advanced than physiologic maturity.

The relationships between reproductive structures number / vascular bundles number (REH), and reproductive structures number / cover surface by phloem (REF) showed important increases from the outer zone to the capitulum center at $E_{2}$ and $E_{4}$ stages situation that tended to stabilize toward $M_{0}$ in base to fits in NER and the progresive differentiation of the conducting tissue that happens toward the capitulum center. Statistical analyses made about the related variables showed a low correlation for REH and an insignificant correlation for REF (Table 2).

Since an earlier stage the outer reproductive structures are constituted in sink better supplied for two fundamental reasons as having earlier the distinguished conducting tissue and for its sourrounding at photoassimilates provision source since the vascular elements penetrate through the outer (Durrieu et al., 1985 and Thevenon, 1996). This determines a clear advantage in competition with seeds located closer to the center of the capitulum to the photoassimilates originated in the leaves that finally to make public by the major weight and size of the outer seeds that usually shows the capitulum. These results support the positive relation between the vascular system development and the photoassimilates accumulation in the capitulum found by Hernández and Palmer (1992). Even though both studied relationships had a similar behavior, it is necessary to clarify that from the physical point of view it is more trustworthy to establish relations based on phloem surface since the translocated photoassimilates quantity is proportional to the area of the phloem vascular elements (Farrar and Williams, 1991).

\section{CONCLUSIONS}

Each parameter considered shows significant variations inside the capitulum and lengthwise of the whole cycle. The more important changes were observed in NER which always showed ascending values from the outer zone to the capitulum center and descending along the cycle. Capitulum expansion was responsible for $46.3 \%$ of this decrease. 
An important void was observed between later floral button $\left(E_{4}\right)$ and flowering beginning $\left(F_{3.2}\right)$ that fundamentally affected NER and NHV. As a wise starting from this critical period is confirmed the appearance of maturity phloem tissue. As a consequence, the relations between NER and the conducting anatomical structures improved slightly. They are essential to secure the seed filling.

\section{ACKNOWLEDGMENTS}

We would like to thank Ing. Agr. Ms. Sc. Guillermo Dosio for providing the capitula used in the present work. We also wish to acknowledge Dr. Luis Hernández for the helpful critical reading of the manuscript and Liliana Miccio for linguistic corrections.

This research was supported by Mar del Plata National University.

\section{REFERENCES}

Bodega, J .L., 1994. Fertilidad floral como determinante del rendimiento en trigo pan (Triticum aestivum L.). Tesis de Magister Scientiae. Facultad de Ciencias Agrarias, Universidad Nacional de Mar del Plata, Argentina.

Chimenti, C.A., Hall, A.J ., 1996. Sensibilidad del número de frutos por capítulo de girasol (Helianthus annuus L.) a cambios en el nivel deradiación durantela ontogenia del cultivo. XXI Reunión Argentina de Fisiología Vegetal. Mendoza, Argentina, pp. 27-28.

D ‘ Ambrogio deArgueso, A., 1986. Manual de técnicas en histología vegetal. Editorial Hemisferio Sur. Buenos Aires, Argentina.

Durrieu, G., Percie du Sert, C., Merrien, A., 1985. Anatomie du capitule de tournesol. Consequences sur la nutrition des akenes. Proceedings $11^{\text {th }}$ International Sunflower Conference, Mar del Plata, Argentina, pp. 7-12.

Esau, K., 1993. Anatomía de las plantas con semilla. Editorial Hemisferio Sur S.A. Buenos Aires, Argentina.

Farrar, J .F., Williams, M.L., 1991. The effects of increasing atmospheric carbon dioxic and temperature on carbon partitioning, source-sink relations and respiration. Plant Cell and Environ., 14: 819-830.

Goffner, D., Cazalis, R., Percie du Sert, C., Calmes, J ., Cavalie, G., $1988 .{ }^{14} \mathrm{C}$ photoassimilate partitioning in developing sunflower seeds. J ournal of Experimental Botany 39, 411-422.

Hernández, L.F., Palmer, J.H., 1992. Incorporation of ${ }^{14} \mathrm{C}$ labelled metabolites into the developing sunflower capitulum. Proceedings of the $13^{\text {th }}$ International Sunflower Conference, Pisa (Italy). Vol. 1, pp. 564-570.

Hernández, L.F., 1995. Pattern formation in the sunflower (Helianthus annuus L.) capitulum. Biophysical considerations. Biocell, 19(3): 203-212.

Matteucci, S.D., Colma, A., 1982. Métodos para el estudio de la vegetación. Secretaría General de la Organización de los Estados Americanos, Washington D.C.

Merrien, A., 1986. Physiologie du tournesol. CETIOM. París.

Sinsawat, V., Steer, B., 1993. Growth of florets of sunflower (Helianthus annuus L.) in relation to their position in the capitulum, shading and nitrogen supply. Field Crops Res., 34, 83100.

Steer, B.T., Hocking, P.J ., Low, A., 1988. Dry matter, minerals and carbohydrates in the capitulum of sunflower (Helianthus annuus L.): Effects of competition between seeds, and defoliation. Field Crops Res., 18, 71-85.

Thevenon, M., 1996. Rendimiento de diferentes zonas del capítulo de girasol y su relación con la vascularización. Tesis de Grado. Facultad deCiencias Exactas y Naturales, Universidad Nacional de Mar del Plata, Argentina.

Villalobos, F.J ., Sadras, F.J ., Soriano, A., Fereres, E., 1994. Planting density effects on dry matter partitioning and productivity of sunflower hibrids. Field Crops Res., 36, 1-11. 


\title{
QUANTIZATION OF REPRODUCTIVE STRUCTURES IN RELATION TO THE VASCULARIZATION OF SUNFLOWER CAPITULUM (Helianthus annuus L.) DURING ITS DEVELOPMENT
}

\author{
RESUMEN
}

El objetivo del presente trabajo fue determinar el número de estructuras reproductivas con relación a la vascularización del capítulo de girasol en tres sectores del mismo: periferia, medio y centro y en cuatro estadíos de desarrollo: $\mathrm{E}_{2}$ (botón floral temprano), $\mathrm{E}_{4}$ (botón floral tardío), $\mathrm{F}_{3.2}$ (principio de floración) y $\mathrm{M}_{0}$ (fin de floración).

Semillas de girasol del híbrido Dekalb G 100 fueron sembradas a una densidad de $72.000 \mathrm{pl} / \mathrm{ha}$ y sus capítulos cosechados en los estadíos indicados.

En cada uno de los estadíos se observaron aumentos significativos del número de estructuras reproductivas presentes desde la periferia hacia el centro del capítulo. EI número de haces vasculares por unidad de superficie de receptáculo mostró una significativa disminución desde la periferia hacia el centro en los estadíos $E_{2}$ y $E_{4}$ y una tendencia a estabilizarse en $F_{3.2}$ y $M_{0}$. Los valores obtenidos de superficie cubierta por floema por $\mathrm{cm}^{2}$ de receptáculo disminuyeron marcadamente desde la periferia hacia el centro en el estadío $E_{4}$, mientras que en $F_{3.2}$ y $M_{0}$ se observaron disminuciones menores pero aún significativas. Las relaciones número de estructuras reproductivas/número de haces vasculares y número de estructuras reproductivas/superficie cubierta por el floema mostraron una baja y despreciable correlación respectivamente.

\section{QUANTIZATION DE STRUCTURES REPRODUCTRICES EN RAPPORT AU VASCULARISATION DE CAPITULE DU TOURNESOL (Helianthus annuus L.) PENDANT SON DÉVELOPPEMENT}

\section{RÉSUMÉ}

L'objectif de ce travail était déterminer le nombre de structures reproductrices, par rapport au vascularization de capitule du tournesol dans trois secteurs de lui: périphérie, milieu et centre, et dans quatre stades de développment: $E_{2}$ (bouton floral tôt), $E_{4}$ (bouton floral plus tardif), $F_{3.2}$ (commencement floraison) et $M_{0}$ (fin floraison) d'après le code CETIOM.

Graines de Dekalb G100 hybride du tournesol ont été semé à 72.000 densité du $\mathrm{pl} / \mathrm{ha}$ et le capitules taillés dans les stades indiquées.

Dans chaque stade a été remarqué augmentations considérables des structures reproductrices présentes compter de l'périphérie au centre de capitule. Le nombre de paquets vasculaires par unité de surface a montré une baisse du significatif de l'périphérie au centre dans $E_{2}$ et $E_{4}$ stades et une tendance à arriver l'écurie à $F_{3.2}$ et $M_{0}$. Les valeurs de surface couvertes par floem par $\mathrm{cm}^{2}$ de capitule obtenus, remarkablely diminué de l'ériphérie au centre dans $E_{4}$ stade pendant que dans $F_{3.2}$ et $M_{0}$ est observé le mineur mais encore baisses importantes.

L'analyse statistique faite sur nombre des structures reproducteur par rapport à nombre des paquets vasculaire et surface couvertes par floem a montré une corrélation basse et insignifiante respectivement. 